UDK 004.773.5:347.93]:614.4

Preliminary communication

\title{
VIDEOCONFERENCE HEARINGS AFTER THE TIMES OF PANDEMIC
}

\author{
Gábor Fekete, LLM, PhD candidate \\ University of Pécs, Faculty of Law \\ H-7633 Pécs, Ybl M. utca 1/b., Hungary \\ gaborfekete@outlook.com
}

\begin{abstract}
The sanitary crisis of the Covid-19 pandemic resulted in several changes in the way courts communicate, can be reached and handle cases. The so-called videoconferencing became one of the accepted ways of the hearings. This kind of videoconferencing took place on online videoconference solutions, which differ a lot from the conventional videoconference systems. After the exceptional situation, it remained a question whether the digital revolution of court proceedings had arrived or the use of videoconferencing should remain an exceptional instrument.

The application of a videoconference system is the subject of the right to a fair trial, in this regard it has been contested by the European Court of Human Rights in several cases. This case law stated several expectations and reveals many aspects, which have to be applied to the online videoconference solutions. On the other hand, the wider use of legal tech instruments is the subject of the political will. The political support is crystallizing within the EU, whose right to act is limited. The interim measures which were introduced under the emergency law regimes on national level show a number of experiences on how the continuous and legally founded functioning of the justice system can be ensured, for example by the use of online video hearings.

The balance between the effectivity and the legality is a crucial question. Upon the above-mentioned sources, the paper introduces the differences of the two methods of videoconferencing. It examines the legal requirements, details the experiences and shows the opportunities of the use of videoconference systems and online videoconference solutions in civil cases.

The use of videoconference in civil hearings can be an instrument conforming to procedural right. The general application of videoconference, especially the online solution lowers the threshold to access the justice, accelerates the procedures, ensures social distancing, but requires both legal and technical preparedness.
\end{abstract}

Keywords: Covid-19, legal tech, litigation, online hearing, pandemic, videoconference 


\section{THE EFFECTS OF THE PANDEMIC}

The judicial branch's key roles, as guardian of civil liberties and protector of the rule of law, can be acutely relevant during public health emergencies, when courts need to function in a manner consistent with their institutional role and their essential characteristic. Courts may also need to issue orders authorizing actions to protect public health or restraining public health actions that are determined to unduly interfere with civil rights ${ }^{1}$. The continuous functioning of the courts in these times is essential; to do that within the framework of the full respect for human rights, and the principles of democracy and the rule of law is crucial.

The first wave of the COVID-19 pandemic in the spring of 2020 hit Europe, and influenced, inter alia, the functioning of the courts and justice systems. The intensity and the seriousness of the sanitary crisis were different among the European countries, but its influence, the fear of the unknown threat was the same and the answers were similar. In these months, from the middle of March till the summer many interim measures were introduced to ensure the social distancing, the universally accepted easiest way to protect ourselves against the virus ${ }^{2}$. Restrictions were also applied in justice systems. The main and typical restrictions were the suspension or postponement of cases, the delay of deadlines, the limitation of the access to courts, the adaptation of online and remote procedures and written proceedings $^{3}$.

The above-mentioned measures were temporary and usually adopted on the basis of the emergency law regime. As the president of the Consultative Council of European Judges (CCJE) pointed out some measures intended short-term may become permanent (e.g. online hearings, etc. $)^{4}$. The expectations show ${ }^{5}$ it is likely that the Covid-19 pandemic will enhance the digitalization of court proceedings and courts. There are many obstacles on this way, both legal and non-legal, such us the 'technical' issues and the cultural attitude.

1 Stier, D.; Nicks, D.; Cowan, G, The courts, public health, and legal preparedness, American Journal of Public Health Vol. 97, 2007., pp. 69-73.

2 Communication of WHO, 2020, [https://www.who.int/westernpacific/emergencies/covid-19/information/physical-distancing], Accessed 13 April 2021.

3 Krans, B. et al., Civil Justice and Covid-19, Septentrio Reports Vol. 5., 2020., pp. 4-57.

4 Betteto, N., Functioning of courts in the aftermath of the COVID-19 pandemic, Consultative Council of European Judges, 2020, [https://rm.coe.int/the-functioning-of-courts-in-the-aftermath-of-the-covid19-pandemic/16809e55ed], Accessed 13 April 2021.

5 Survey on the Accelerate digitization to increase resilience, Deloitte, 2020, [https://www2.deloitte.com/ content/dam/Deloitte/global/Documents/Legal/dttl-legal-covid-respond-legal-digitization.pdf], Accessed 13 April 2021. 
In a wider view, the pandemic is accelerates several "tectonic shifts" in the functioning of justice. The technology-enabled future of courts arrived earlier, by the forced adaptation of the use of the existing IT solutions. The wider use of online tools may erode the gatekeeper role of lawyers. ${ }^{6}$

The ongoing restrictions of the "new normal" effects significant challenges to the civil, political and economic rights of everyone. The paper introduces the measures that have been taken in Hungary in this field and also examines the legal obstacles on the way of further digitalization of court proceedings on the basis of the ECtHR's case-law on hearings held via video link.

\section{THE EFFECTS OF DIGITALIZATION ON THE PROCEDURAL RIGHTS}

The digitalization of court proceedings and in a wider scope the legal tech is a new, enormous hot topic. During the first wave, many countries turned to remote hearings as an alternative to in-person hearings. The so-called videoconferencing became part of our daily life and it does not require special investments and developments, like other possible tools of court digitalization.

With the introduction of a new instrument, the question arises: how does it fit into the legal environment? This question is much more adequate in connection with the application of brand new IT technologies, like the online videoconference platforms.

\subsection{Legal frameworks of videoconference systems in the EU}

The Treaties do not contain any special provisions for information and communication technologies. The EU took relevant actions within the framework of sectoral and horizontal policies. Theses actions' peek can be found in the Digital Single Market Strategy ${ }^{7}$ and in the achievements of the European area of justice ${ }^{8}$, especially in the field of judicial cooperation.

The use of videoconference systems was not an unknown instrument in the field of the judicial cooperation in civil matters in the EU. The European e-Justice action

Engstrom, D.F., Post-Covid Courts, U.C.L.A. Law Review, Vol. 46, 2020., pp. 246-267.

European Commission, A Digital Single Market Strategy for Europe, 2020, [https://eur-lex.europa.eu/ legal-content/EN/TXT/?uri=celex\%3A52015DC0192], Accessed 13 April 2021.

8 Barrot, J., The EU's Area of Freedom, Security and Justice: Successes of the last ten years and the challenges ahead, in: Guild, E.; Carrera, S.; Eggenschwiler, A. (eds.), The Area of Freedom, Security and Justice ten years on Successes and future challenges under the Stockholm Programme, Brussels, 2010., pp. 13-18. 
plan approved by the Council in November $2008^{9}$ emphasized the importance of the simplification and encouraging communication between the Member States' judicial authorities and found videoconferencing or secure electronic networks a proper instrument for that.

The European e-Justice action plan lists "Better use of videoconferencing" as one of the projects on which work should continue in 2009-2013. In cross-border cases, communication between judicial authorities of different Member States is crucial. In the framework of European e-Justice, the Member States of the EU have agreed to work together to promote the use of videoconferencing and to exchange experience and best practices. The legislative framework is different in crimina ${ }^{10}$ and civil ${ }^{11}$ matters, but the technical and practical issues, and also the aim is similar: to provide an effective tool and a greater flexibility for when and how witnesses or experts are required to give evidence or to ensure the presence of a party who is unable to be presented in person.

Within the EU in civil and commercial cases, the use of videoconference systems is most applied on the basis of the 1206/2001/EC regulation on cooperation between the courts of the Member States in the taking of evidence in civil or commercial matters ${ }^{12}$. The regulation does not define 'videoconference' and does not mention any other type of technologies. In this way it offers flexibility to ensure the efficient taking of evidence regardless of the means ${ }^{13}$. In this way it leaves in the Member States' hand to choose the proper (existing) method of videoconference, which can easily result in technical compatibility problems. The lack of exchange of technical parameters is an identified problem of the regulation ${ }^{14}$, and causes extra work for the coordinating central authorities or the failure of evidence

9 Notice of the Council on Multi-annaul European E-Justice action plan 2009-2013, OJ C 75, 31.3.2009, p. 1-12.

10 the related regulations are the following: Convention on Mutual Assistance in Criminal Matters between the Member States of the European Union (Article 10), Council Directive relating to compensation to crime victims (Article 9(1))., Council Framework Decision on the standing of victims in criminal proceedings (Article 11(1)).

11 the related regulations are the following: Council Regulation on cooperation between the courts of the Member States in the taking of evidence in civil and commercial matters (Article 10(4) and Article 17(4)), Regulation EC No. 861/2007 of the European Parliament and of the Council establishing a European Small Claims Procedure (Articles 8 and 9(1)), Directive 2008/52/EC of the European Parliament and of the Council on certain aspects of mediation in civil and commercial matters.

12 1.4. point of the Final Report of the Informal Working Group on Cross-border Videoconferencing, 2014, [https://e-justice.europa.eu/fileDownload.do?id=dd1801f0-6a44-43a9-b84b-7859bbe094b2], Accessed 13 April 2021.

13 Miguel, T., Cross-Border Litigation: 'Videotaking' of Evidence within EU Member States, Dispute Resolution International Vol. 12, 2018, pp. 71-95.

14 Final Report, op. cit., note 12, 3.3 point. 
taking. The scope of the regulation is the evidence taking, and it is not applicable for hearing the parties or to hold e-hearings.

With the introduction of the European small claim procedure, the EU found a special European civil procedure and reached the goal set in the Tampere Program, and detailed in the Hague Program ${ }^{15}$ in this field. The new procedure steps forward with the scope of application of videoconferencing. Besides defining it as a tool of taking evidence, it also creates the option to hold an oral hearing through videoconference or other communication technology if the technical means are available ${ }^{16}$.

The EU does not have the competence to act on the unification of the Member States' rules on the use of videoconference systems or other types of communication systems, especially at national level. There is an ongoing pilot program for the exchange of case-related data in cross-border legal procedures, the European e-Justice Digital Service Infrastructure (e-CODEX). It has been developed to interlink existing national and European ICT systems in the eJustice domain. The system has been initially tested between piloting countries starting with the European Order for Payment and EU Small Claim procedures. ${ }^{17}$

The existing rules and experiences of the taking evidence and the small claim procedure with the mixing of the facilitative effect of the pandemic in this field, may result in more ambitious cooperation at EU level. The ambition to facilitate the cooperation between the Members States can be seen in the ongoing legislative procedure about the computerised system for communication in cross-border civil and criminal proceedings ${ }^{18}$.

\subsection{Case law of the ECtHR concerning hearings via video link}

From the legal point of view, the application of a videoconference system ensures the accessibility of the procedure, the presence of the party, the equality of arms,

15 3.4.1 point of the Information of the Council on The Hague Programme: strengthening freedom, security and justice in the European Union, [2005], OJ 2005/C 053/1, pp 1-15.

16 Article 8 of the Regulation of the European Parliament and of the Council 861/2007/EC on establishing a European Small Claims Procedure, [2007], OJ L 199, 31.7.2007, pp. 1-22.

17 Velicogna, M., Cross-border Civil Litigation in the EU: What can we learn from COVID-19 emergency National e-Justice experiences?, ‘’ Meets Justice webcast, 2020, [https://papers.ssrn.com/sol3/Delivery.cfm/SSRN_ID3737648_code835984.pdf?abstractid=3737648\&mirid=1], Accessed 13 April 2021.

18 Legislative proposal of the European Commission on A computerised system for communication in cross-border civil and criminal proceedings (e-CODEX system), and amending Regulation (EU) 2018/1726, 2020, [https://www.europarl.europa.eu/RegData/docs_autres_institutions/commission_ europeenne/com/2020/0712/COM_COM(2020)0712_EN.pdf ], Accessed 13 April 2021. 
and the publicity of the hearings. These topics fall within the scope of the right to a fair trial.

The right to a fair trial is granted by Article 6 of European Convention on $\mathrm{Hu}$ man Rights (the Convention). In a different way it is applicable both in civil and criminal procedures. The content of the right and its differences based on the type of the procedure are interpreted in several judgements of the European Court of Human Rights (ECtHR). Also, the use of a videoconference system has been contested, and adjudged in several cases of the ECtHR.

The first time when the ECtHR examined the compatibility of the use of a video link with the right to a fair trial was in 2006, in the case of Marcello Viola v. Italy ${ }^{19}$. This case became the origo of the cases, where the question involves the use of a videoconference system, therefore the detailed exploration of the case is reasonable.

The above-mentioned case is based on a criminal procedure. The applicant was accused of serious crimes, and was subject to restricted prison regime. The alleged violation was that he was forced to use videoconference on his hearing, which created difficulties for his defence.

The general finding of the ECtHR was that the defendant's participation in the proceedings by videoconference as such is not contrary to the Convention, if it serves a legitimate aim and if the arrangements for the giving of evidence are compatible with the requirements of respect for due process. The requirement of respect for due process was examined from two angles: the necessity of the restriction of in person presence and the rights of the defence.

Within the framework of the reasons behind the restriction of in person presence, the ECtHR examined the following circumstances: prevention of disorder, prevention of crime, protection of witnesses and victims of offences in respect of their rights to life, freedom and security, and compliance with the "reasonable time" requirement in judicial proceedings.

Within the framework of the rights of the defence, the ECtHR examined the following: the effective presence of the applicant, and the right to legal counsel. In connection with the right to effective presence, the ECtHR examined, if the video link allowed the applicant to see the persons present and hear what was being said; if he could also be seen and heard by the other parties, the judge and the witnesses, and had an opportunity to make statements to the court from his place of deten-

19 [2006], ECHR 2006-XI 123. 
tion. Also, it took into account technical problems, for example if there were any difficulties in the transmission of the voice or images.

In connection with the right to legal counsel, the ECtHR examined, if the defence counsel had the right to be present where his client was situated and to confer with him confidentially.

In the certain case, the ECtHR found that the use of videoconference was compatible with the right to a fair trial, because the use of a special hearing method was reasonable, inter alia, because of safety measures and to be in compliance with the "reasonable time" requirement. The use of video link was applied only in the appeal hearings, which did not put the defence at a substantial disadvantage as compared with the other parties to the proceedings, and that the applicant had an opportunity to exercise the rights and entitlements. Furthermore, it pointed out there were no technical issues involved, because there were no times when the defence sought to bring to the attention of the court difficulties in hearing or seeing.

The ECtHR in the case of Sakhnovskiy v. Russia ${ }^{20}$ cited the above-mentioned findings of the Marcello Viola v. Italy case in connection with the effective presence on an appellate hearing via videoconference. The subject of the case concerned the accused applicant's right to communicate with his lawyer, in this aspect the case introduced new findings.

In connection with the right to communicate with a lawyer, the ECtHR emphasized that the Convention is intended to "guarantee not rights that are theoretical or illusory but rights that are practical and effective" and if a lawyer were unable to confer with his client and receive confidential instructions from him without the risk of surveillance, his assistance would lose much of its usefulness. In the certain case the applicant was able to communicate with the newly appointed lawyer for fifteen minutes, immediately before the start of the hearing, which was considered not efficient, therefore found not compatible with the right to a fair trial. In connection with the video link, which was installed and operated by the state, the ECtHR found questionable the sufficient privacy of the communication and accepted that the applicant might legitimately have felt ill at ease when he had a discussion with his lawyer.

As we saw in the above-mentioned cases, the ECtHR in connection with the presence via video link handles the hearings differently based on whether it is a first instance hearing or an appellate one. In the case of Trepashkin v. Russia (No. 2) ${ }^{21}$

\footnotetext{
20 [2010], Application no. 21272/03.

21 [2010], Application no. 14248/05.
} 
the ECtHR notes that the Convention case-law under Article 6 does not require the same level of guarantees in the court of appeal as at the trial stage. Thus, provided that a public hearing has been held at first instance, a less strict standard applies to the appellate level, at which the absence of such a hearing may be justified by the special features of the proceedings at issue. In the certain case, the ECtHR reiterates the reasoning of an admissibility decision ${ }^{22}$ which says that the physical presence of an accused in the courtroom is highly desirable, but it is not an end in itself: it rather serves the greater goal of securing the fairness of the proceedings, taken as a whole. In this case, the ECtHR found no violation of Article 6 in a case where the applicant's presence on the appellate hearing was ensured by a video link, under circumstances where no malfunction of the IT system was found, and the right to effective defence was ensured.

The first case, where the use of videoconference was examined in connection with a civil case, was the case of Vladimir Vasilyev v. Russia ${ }^{23}$. In connection with the question of the in person presence on the hearings, the ECtHR pointed out the difference between the criminal and civil cases. It reiterated its case law about the interpretation of Article 6 of the Convention, which does not guarantee the right to be heard in person at a civil court, but rather a more general right to present one's case effectively before the court and to enjoy equality of arms with the opposing side.

In the certain case, the applicant - while he was serving his prison sentence brought a civil case, in which his claim was rejected. The applicant kept in contact with the court in writing, and never was present or represented at the hearings. The subject of the case was personal so it would require the in person hearing of the applicant. The ECtHR found that the national court did not consider how to ensure effective participation for the applicant, despite the fact that there were options to do so. In the ECtHR's view, to hold a session by way of a video link would have been an appropriate option.

In the case of Yevdokimov and Others v. Russia ${ }^{24}$, the ECtHR reiterated its finding, that the use of a video link could be an obvious solution to conduct civil proceedings, where the personal hearing of a party is required. The personal hearing of a party may be required if the claim involves the party's personal experience and, accordingly, whether the court needs to take oral evidence directly from the party. The ECtHR cited its findings taken in the above-mentioned criminal based

Case of Golubev v. Russia, [2002], Application no. 26260/02.

[2012], Application no. 28370/05.

[2016], Application no. 27236/05, 44223/05, 53304/07, 40232/11, 60052/11, 76438/11, 14919/12 , 19929/12, 42389/12, 57043/12 and 67481/12. 
cases and expressed that the use of videoconference can be compatible with Article 6 if the party is able to follow the proceedings, see the persons present and hear what is being said, but is also able to be seen and heard by the other parties, the judge and witnesses, without technical impediment.

In the case of Gorbunov and Gorbachev v. Russia ${ }^{25}$, the ECtHR reiterated the described findings. The poor connection of videoconference prevents the party to follow the proceedings in an adequate way if the only way of communication between the applicant and his lawyer carried out on a videoconference system installed and operated by the state results in the lack of confidential communication between them. These circumstances on the basis of the lack of effective presence and the lack of right to communicate with the lawyer result in the infringement of the right to a fair trial.

In the case of Sakhnovskiy v. Russia (No. 2) ${ }^{26}$, which is based on the alleged lack of confidential communication between the applicant and his lawyer, the ECtHR pointed out, that it took into consideration the fact, that the state did not provide any evidence that the video link was secured against any attempt at interception, or offer any explanation why it was not possible to organize at least a telephone conversation between the applicant and the lawyer or to appoint a local lawyer who could have visited the applicant in the remand prison. These circumstances may be a good compass, to ensure the right to communicate with the lawyer.

On the basis of the cited case law of the ECtHR, it seems the use of a videoconference system is an "appropriate option" and "obvious solution" to conduct civil proceedings. As the cited cases also show, the use of a videoconference system always comes together with some restrictions of rights and opportunities of the parties. The interference of the restrictions with Article 6 of the Convention depends on the question of the proportionality. A restriction due to the special way of the hearing can conform with the right of a fair trial if within the circumstances of the exact case the restriction is proportional regarding the influenced right.

Although the question is complex, the legal aim and the compatibility with the requirements of respect for due process are the universal measures of the proportionality.

The legitimate aim can be varied, as the examined cases show the safety measures and the compliance with the reasonable time requirement can be a legitimate aim.

[2016], Application no. 43183/06 and 27412/07.

[2018], Application no. 39159/12. 
The party's right to an effective presence, as a part of respect of due process is handled differently in criminal and civil cases, and also in the different stages of the procedure. In civil cases, the in person hearing of the party is not essential, if his side is presented effectively in another way. The guarantees of Article 6 at the different procedural levels of the remedy do not require the same level as at the first instance.

The mentioned specialties of the civil cases and the different stages of the procedure lower the threshold of what can be deemed as a legitimate aim to found the use of videoconference systems. In civil cases, the parties' request based on their financial reason or time saving may also constitute a legitimate aim to hold a hearing via videoconference.

The examined case law in connection with the equipment of videoconference is technology-neutral. Based on the presented cases, if there are no technical malfunctions and difficulties in hearing or seeing, the videoconference system can be any kind. The security of the connection is a question only if confidential communication takes place. In civil cases, the confidential communication arises only in a few situations, in case of a closed hearing, confidential communication between the party and the legal counsel and if the identities of the witnesses are hidden. The confidential communication between the party and the legal counsel - based on the ECtHR findings in the case of Sakhnovskiy v. Russia (No. 2) - could take place on the telephone or mutatis mutandis by direct messaging, in a civil case maybe simultaneously with the hearing and hidden from the other participants.

In the author's view, upon the above presented ECtHR case law there is no general legal obstacle in the Convention to use online video platforms at civil case hearings. The cases where confidential communication should take place could be an exception from it. With the fulfillment of the described conditions, holding a hearing via online video connection can be applied for a wide range of reasons, especially upon the parties' request in civil cases.

\section{NEWLY INTRODUCED RULES OF THE USE OF THE VIDEOCONFERENCE SYSTEMS IN HUNGARY, THE E-HEARINGS}

As many other Member States of the EU, Hungary on $11^{\text {th }}$ March, 2020 also declared the state of danger for the elimination of the consequences of the human epidemic $^{27}$. The declaration of the state of danger was followed by two weeks of

27 Hungary, Government Decree no. 40/2020 (11 March) on the declaration of state of danger, Official Gazette of HungaryNo. 39/2020. 
total lockdown in almost every part of life, also in the operation of the judicial system, where extraordinary court vacation was ordered ${ }^{28}$.

Because of the lack of legal preparedness, these weeks of the lockdown introduced days full of uncertainty and resulted in the freeze of procedures. Only the urgent cases were handled, sometimes in procedural manner that deemed practical but not legally founded. The extraordinary manner of the situation and the abovementioned circumstances were similar to the situation experienced by other MSs' lawyers in their countries ${ }^{29}$.

The legal bases of the continuous functioning of the courts were introduced on $31^{\text {st }}$ March, $2020^{30}$, among these the new rules of the application of the electronic communications network were introduced, which legally widened the applicability of the existing infrastructure.

\subsection{The basis of electronic communication in the civil procedural law of Hungary}

The Code of Civil Procedure of Hungary has had rules on ways of electronic communications for a long time and defines two types of it: the electronic communication and - in its first, and miraculous name - the closed-circuit telecommunications network. The electronic communication is the instrument that ensures the electronic identification of the clients and enables document transfer between the court and the identified client. The closed-circuit telecommunications network was the instrument that ensured the hearing of the party and other litigants, and experts, and the examination of witnesses via a videoconference system, the new code changed its name to 'conduct interview on electronic communications network'.

The use of electronic communication was introduced in 2010 and was optional in certain cases, and it gradually became available in a wider range of procedures, then became mandatory in some procedures. The end of this gradual development was achieved by the new Code of Civil Procedure, which entered into force on $1^{\text {st }}$ January, 2018 ${ }^{31}$. The new Code made the obligation to use electronic means gen-

28 Section 1 of Hungary, Government Decree no. 45/2020 (14 March) on the measures to be taken during the state of danger declared for the prevention of the human epidemic endangering life and property and causing massive disease outbreaks, for the elimination of its consequences, and for the protection of the health and lives of Hungarian citizens (II), Official Gazette No. 42/2020.

29 Krans, B. et al., Civil Justice and Covid-19, Septentrio Reports Vol. 5., 2020., pp. 4-57.

30 Hungary, Government Decree 74/2020 (31 March) on certain procedural measures applicable during the period of state of danger, Official Gazette No. 59/2020.

31 Szalai, P., Elektronikus kommunikáció a polgári perben, in: G. Karácsony, G. (ed.), Az elektronikus eljárások joga, Budapest, 2018., pp. 7-36. 
eral for economic operators, organs of the State and the legal counsels of clients and optional for others in every type of cases ${ }^{32}$.

The option to conduct an interview on electronic communications network was introduced in 2015 in civil cases, but is has earlier roots in the criminal procedure, where it has been available since 2003. The main rules of the use earlier and the present Code of Civil Procedure, the rules of the 'closed-circuit telecommunications network' and 'the conduct interview on electronic communications network' are mostly the same. The main rules are the following.

The court shall order to conduct the hearing through electronic communications networks based on a request of a party or ex officio. It can be ordered if it has a legitimate aim: if it is reasonable, particularly if it is likely to expedite the process, or the personal presence would entail considerable hardship or unreasonably higher costs, or if it is necessary to ensure the safety of a witness.

The law does not determine the type of the videoconference system or the equipment that has-to be used for this procedure. The equipment of this kind of hearing must be capable of simultaneous transmission of video and audio signals in real-time. This requirement is technology-neutral. The rules also determine the legal requirements of the hearings, which results in the fact that the hearing can be carried out only by a special videoconference system which is installed and operated by the state.

Among the legal requirements, the interview has to take place in a court, or any other body with required facilities and lead by a judge or by an assistant judge. In the second place, the equipment has to meet strict rules of visibility. It has to ensure that the person interviewed, and all other persons present together with the person heard can be seen by the persons attending the hearing. Furthermore, all areas of the premises designated for hearings via electronic communications network must be kept visible for the presiding judge. The person questioned in the premises specifically designed for hearings via electronic communications network shall also be able to monitor the hearing. At last, the equipment has to be capable of ensuring the holding of a confidential interview, where the identities of the witnesses are hidden from the attending persons, except the presiding judge, by the distortion of the video or sound signal or both signals during transmission.

On the basis of the described rules, the required videoconference system was installed in the courts. By the end of the year 2019, 184 courtrooms were fully equipped ${ }^{33}$,

32 Art. 609. (1) of Act CXXX of 2016 on the Code of Civil Procedure, Official Gazette of Hungary No. $190 / 2016$.

33 Court news, Courts of Hungary, [2019], [https://birosag.hu/en/news/category/about-courts/soon-184courtrooms-will-be-available-remote-hearings], Accessed 13 April 2021. 
which resulted, that every court building in Hungary has been equipped with the electronic communication system called ViaVideo system. The system is capable of the simultaneous transmission of video and audio signals in real-time, ensures the above-mentioned visibility requirements and confidential interview, and also has a special inspection camera to carry out inspection of subject-matter or documents.

The above-mentioned rules of the use of electronic communications network also determine that the use of these procedures requires more court area, at least two courtrooms or a courtroom and one more official room and more officials. These requirements cannot be fulfilled in the times of pandemic, when the availability of the officials is tight and the restrictions on the right to free movement and the use of court buildings are applied. It also has to be noted, that the mentioned infrastructure, its bandwidth and the number of endpoints were designed to be operated in case of special needs, not for a general use.

\subsection{Temporary rules of videoconferencing due to the pandemic in Hungary}

Within the framework of the existing rules, there was no option to hold hearings via videoconference system or to conduct hearing in this way without the presence of the interviewed person in a court building or in another designated official place. There was no option to use electronic communications network without the involvement of additional court staff beside the presiding judge. Therefore, the applied restrictions of the lockdown, like social distancing, quarantine, restricted entry to court buildings could not have been handled by the existing rules of interviewing on an electronic communications network. These rules were designed to hear remotely one person in special need, but not to hold remote hearings in a high number. The introduced exceptional procedural measures ${ }^{34}$ applicable during the period of state of danger handled this problem.

The new measure widened the option to use an electronic communications network in two ways. Firstly, the wording and the aim of the ruling changed, the electronic communications network can be used not only to conduct an interview, but also to hold hearings. Secondly, the new rules enabled the courts to hold hearings remotely by way of an electronic communications network or other means suitable for electronic image and sound transmission, if doing so is necessitated by epidemiological measures. ${ }^{35}$

This exceptional way of electronic communication is not regulated in a detailed way. The term 'suitable' means the acceptance of a method depends on the deci-

\footnotetext{
34 Hungary, Government Decree 74/2020 (31 March).

35 Section 21. (2) of Hungary, Government Decree 74/2020 (31 March).
} 
sion of the presiding judge. The strict part of this new option comes from its name, it has to be able to maintain simultaneous audio and video connection. It results that the telephone conference is not a suitable way, but the use of online video platforms is an option.

The new option to hold e-hearings is a great facilitation of the use of electronic communications network methods, because it solves some of the revealed tight points of the system, by enabling the courts to use online videoconference systems.

The opinion of the Civil Chamber of the Curia of Hungary ${ }^{36}$ filled the gap due to the lack of detailed rules of e-hearings. The opinion declared the related regulation as the rules of the e-hearing. The e-hearing is a new phenomenon in the Hungarian civil procedure despite the fact that it partly stands on the rules of the use of electronic communications network. The Curia emphasizes that the rules of ehearing are based on emergency law regime and the part, where there is no special rule declared, shall be applied with the Code of Civil Procedure.

Upon the opinion, in cases, where it was required to hold a hearing, it was obligatory to hold it as an e-hearing. It meant the court had to examine if the participant (parties, counsels, witness etc.) are able to take part in an e-hearing, if they have the required technical resources or not. The e-hearing could be avoided only if the participants do not have the required technical resources or a special contribution needed, that could not be acted on at an e-hearing.

The e-hearing generally is a public hearing, its publicity is ensured in the court. In the case when a closed hearing is ordered, the presiding judge has to reveal if the places of the participants fulfilling the requirements of a closed hearing is ensured or not. When the issue is capable of being adjudged, the e-hearing shall be closed, the court shall adopt a judgment outside the hearing.

The Hungarian courts uniformly used Skype for business to hold e-hearings.

By the end of the state of danger in Hungary, the so-called state of epidemiological preparedness began ${ }^{37}$ and due to the continuous threat of the pandemic, the legislator kept the option of e-hearings in cases when it is necessary because of the applied defensive measures due to the pandemic ${ }^{38}$. The legitimate aim to hold an e-hearing changed and ensures wider discretion for the presiding judge. At the same time, the regulation remained short, no detailed rules of the e-hearing pro-

\footnotetext{
36 Opinion 2/2020 of 30 April 2020 of the Civil Chamber of the Curia of Hungary.

37 Act. LVIII of 2020 on Temporary rules in connection with the termination of state of emergency and rules of the state of epidemiological preparedness, Official Gazette of Hungary No. 144/2020.

38 Art. 138. (1) of Act. LVIII of 2020.
} 
cedure were acted, and the above-mentioned opinion of the Civil Chamber of the Curia of Hungary is not applicable anymore. The opinion was applicable within the framework of the law regime of state of danger, but not in the law regime of state of epidemiological preparedness.

\section{THE FUTURE OF THE USE OF ONLINE VIDEO PLATFORMS IN CIVIL JUSTICE}

The two types of the attitude in connection with the use of new technologies cannot be allowed to influence the legislator in the decision making process about the further use of e-hearings. Neither the avoidance, nor the excessively optimistic attitude can be taken into account in this question; the decision has to stand only on a legal base. The legal requirements both in the case law of the ECtHR and in the EU legislation are technology neutral. The strict procedural rules tighten the range of possible infrastructure of e-hearings. The necessity to ease these procedural rules and the way of it shall be a subject of consideration. The experiences of using videoconference systems, and the experiences of the times of pandemic about the use of online video platforms have to be taken into account.

Videoconference technology supports the quality of justice, inter alia, because videoconference, especially via online video platforms effortlessly bridges locations that are separated by great distances. In this aspect, it enhances the access to justice and reduces the procedural costs and delays. ${ }^{39}$ The wider accessibility supports equality and legal certainty and stresses that videoconference is more than a cost-effective tool. ${ }^{40}$ The online videoconference systems are more easily available for everyone and require less human or material resources of courts than the use of the state operated videoconference systems would.

On the other hand, the preparation for the court system to use online video conference systems has resource requirements. It requires both infrastructural investment and additional human resources, to operate the system on a daily basis and serve a support ${ }^{41}$. It also requires some financial resources, because the business use of this platform and the functions, which are required in a business use, have a price or fee. In certain cases, additional infrastructure development is required, if the copies of the conference should be saved or the encryption of the stream has to be ensured by own equipment.

\footnotetext{
39 Sourdin, T., et al., COVID-19, Technology and Family Dispute Resolution, 2020, [https://papers.ssrn. com/sol3/papers.cfm?abstract_id=3672995], Accessed 13 April 2021.

$40 \quad$ Final Report, op. cit., note 12, 1.4 point.

$41 \quad$ Final Report, op. cit., note 12, 3.3 point.
} 
In addition to the legal requirements detailed on the ECtHR case law, the experiences also show the negative side if a hearing takes place in a videoconference system. Because of the lack of the "atmosphere of the officiality", parties do not fully appreciate the seriousness or finality of proceedings. The technical issues with technology can make the effective presence more difficult. The lack of the opportunity to observe the non-verbal behaviors makes it harder for the parties to follow procedure, and for the presiding judge to adjudge the credibility of the participants or to identify vulnerability and give support. ${ }^{42} 43$

\section{CONCLUSION}

The expectation arisen from the restrictions of the pandemic was to see how the continuous and legally founded functioning of the justice system can be ensured and how to balance between effectivity and legality. The courts were forced to focus more on the digital solutions. As the introduced example of Hungary shows, the technical preparedness of courts can swiftly serve these expectations.

The question of the use of modern technology in court procedures is not a new one, in some aspects, for example, the use of videoconference solutions has already been dealt with in several cases by the ECtHR and has become part of EU legislation.

The development of information technology has created challenges for the justice systems in at least two aspects. On the one hand, the new types of legal relations created within the online sphere cannot be handled within the legislative framework of the traditional civil procedure. On the other hand, the expectations have been changed. ${ }^{44}$ Modern society demands that justice be delivered swiftly and effectively, even in "real time". ${ }^{45}$ The new features of electronic civil procedure,

42 Denault, V.; Patterson, M.L., Justice and Nonverbal Communication in a Post-pandemic World: An Evidence-Based Commentary and Cautionary Statement for Lawyers and Judges, Journal of Nonverbal Behavior, Vol. 45, 2021, pp. 1 - 10.

43 Ryan, M.; Harker, L.; Rothera S. Remote hearings in the family justice system: reflections and experiences, Nuffield Family Justice Observatory/The Legal Education Foundation, 2020, [https://www.nuffieldfjo.org.uk/app/nuffield/files-module/local/documents/remote_hearings_sept_2020.pdf], Accessed 13 April 2021.

44 Osztovits, A., Online biróságok és az igazságszolgáltatáshoz való jog - esély vagy veszély?, Magyar Jog, Vol. 67, No. 11, 2020, pp. $625-632$.

45 Lord Chief Justice of England And Wales, First International Forum on Online Courts: the Cutting Edge of Digital Reform, 2018, [https:/www.judiciary.uk/wp-content/uploads/2018/12/speech-lcjonline-court.pdf], Accessed 13 April 2021. 
namely immateriality, connection, intermediality, interaction, hyper-reality, instantaneousness and deterritorialization are identified. ${ }^{46}$

The challenge has been changed; modern technology should not only be used, but should be implemented in court procedures.

The use of online video platforms serves the effectivity of court operations and increases the accessibility of justice, but interferes with the fairness of trial. Within the framework of the implementation of new technologies, in connection with the use of online video platforms, the paper examined how the temporary rules should be kept and implemented as a general rule.

The case law of the ECtHR set up the general requirements of how to use videoconference systems in a way that fulfills the requirements of the right to a fair trial. The EU has taken several steps in the use of electronic communication technologies and set a new goal to enhance the digitalization of the European economy and courts.

Based on the above and on the experiences of the pandemic, the digital transformation of the civil procedures is the most important question of the civil procedural law and it will be one of the biggest changes in this field of law.

\section{REFERENCES}

\section{BOOKS AND ARTICLES}

1. Barrot, J., The EU's Area of Freedom, Security and Justice: Successes of the last ten years and the challenges ahead, in: Guild, E.; Carrera, S.; Eggenschwiler, A. (eds.), The Area of Freedom, Security and Justice ten years on Successes and future challenges under the Stockholm Programme, Brussels, 2010., pp. 13-18

2. Krans, B., et al. Civil Justice and Covid-19, Septentrio Reports Vol. 5, 2020., pp. 4-57

3. Calmon, P., The Future of the Traditional Civil Procedure, in: Kengyel, M.; Nemessányi, Z. (eds.), Electronic Technology and Civil Procedure: New Paths to Justice from Around the World, 2012, pp. 67-87

4. Denault, V.; Patterson, M.L., Justice and Nonverbal Communication in a Post-pandemic World: An Evidence-Based Commentary and Cautionary Statement for Lawyers and Judges, in: Journal of Nonverbal Behavior, Vol. 45, 2021, pp. 1 - 10

5. Engstrom, D. F., Post-Covid Courts, U.C.L.A. Law Review, Vol. 46, 2020, pp. 246-267

6. Miguel, T., Cross-Border Litigation: 'Videotaking' of Evidence within EU Member States, Dispute Resolution International Vol. 12, 2018, pp. 71-95

46 Calmon, P., The Future of the Traditional Civil Procedure, in: Kengyel, M.; Nemessányi, Z. (eds.), Electronic Technology and Civil Procedure: New Paths to Justice from Around the World, 2012, pp. 67-87. 
7. Osztovits, A., Online biróságok és az igazságszolgáltatáshoz való jog - esély vagy veszély?, Magyar Jog, Vol. 67, No. 11, 2020, pp. 625 - 632

8. Stier, D.; Nicks, D.; Cowan, G, The courts, public health, and legal preparedness, American Journal of Public Health Vol. 97, 2007, pp. 69-73

9. Szalai, P., Elektronikus kommunikáció a polgári perben, in: G. Karácsony, G. (ed.), Az elektronikus eljárások joga, Budapest, 2018, pp. 7-36

\section{ECHR}

1. European Convention for the Protection of Human Rights and Fundamental Freedoms, as amended by Protocols Nos. 11 and 14, 4 November 1950, ETS 5

2. Case of Golubev v. Russia, [2002], Application no. 26260/02

3. Case of Marcello Viola v. Italy, [2006], ECHR 2006-XI 123

4. Case of Sakhnovskiy v. Russia, [2010], Application no. 21272/03

5. Case of Trepashkin v. Russia (No. 2), [2010], Application no. 14248/05

6. Case of Vladimir Vasilyev v. Russia, [2012], Application no. 28370/05

7. Case of Yevdokimov and Others v. Russia [2016], Application no. 27236/05, 44223/05,

8. $53304 / 07,40232 / 11,60052 / 11,76438 / 11,14919 / 12,19929 / 12,42389 / 12,57043 / 12$ and $67481 / 12$

9. Case of Gorbunov and Gorbachev v. Russia, [2016], Application no. 43183/06 and 27412/07

10. Case of Sakhnovskiy v. Russia (No. 2), [2018], Application no. 39159/12

\section{EU LAW}

1. Information of the Council on The Hague Programme: strengthening freedom, security and justice in the European Union, OJ 2005/C 053/1, pp 1-15

2. Regulation of the European Parliament and of the Council 861/2007/EC on establishing a European Small Claims Procedure, [2007], OJ L 199, 31.7.2007, pp. 1-22

3. Notice of the Council on Multi-annaul European E-Justice action plan 2009-2013, OJ C 75, 31.3.2009, pp. 1-12

\section{LIST OF NATIONAL REGULATIONS, ACTS AND COURT DECISIONS}

1. Art. 609. (1) of Act CXXX of 2016 on the Code of Civil Procedure, Official Gazette of Hungary No. 190/2016

2. Act. LVIII of 2020 on Temporary rules in connection with the termination of state of emergency and rules of the state of epidemiological preparedness, Official Gazette of Hungary No. $144 / 2020$

3. Hungary, Government Decree no. 40/2020 (11 March) on the declaration of state of danger, Official Gazette of Hungary No. 39/2020

4. Hungary, Government Decree no. 45/2020 (14 March) on the measures to be taken during the state of danger declared for the prevention of the human epidemic endangering life and 
property and causing massive disease outbreaks, for the elimination of its consequences, and for the protection of the health and lives of Hungarian citizens (II), Official Gazette of Hungary No. 42/2020

5. Hungary, Government Decree 74/2020 (31 March) on certain procedural measures applicable during the period of state of danger, Official Gazette of Hungary No. 59/2020

6. Opinion 2/2020 of 30 April 2020 of the Civil Chamber of the Curia of Hungary

\section{WEBSITE REFERENCES}

1. Betteto, N., Functioning of courts in the aftermath of the COVID-19 pandemic, Consultative Council of European Judges, 2020, [https://rm.coe.int/the-functioning-of-courts-in-theaftermath-of-the-covid-19-pandemic/16809e55ed], Accessed 13 April 2021

2. Court news, Courts of Hungary, 2019, [https://birosag.hu/en/news/category/about-courts/ soon-184-courtrooms-will-be-available-remote-hearings], Accessed 13 April 2021

3. European Commission, A Digital Single Market Strategy for Europe, 2020, [https://eur-lex. europa.eu/legal-content/EN/TXT/?uri=celex\%3A52015DC0192], Accessed 13 April 2021

4. Final Report of the Informal Working Group on Cross-borderVideoconferencing, 2014, [https://ejustice.europa.eu/fileDownload.do?id=dd1801f0-6a44-43a9-b84b-7859bbe094b2],Accessed 13 April 2021

5. Legislative proposal of the European Commission on A computerised system for communication in cross-border civil and criminal proceedings (e-CODEX system), and amending Regulation (EU) 2018/1726, 2020, [https://www.europarl.europa.eu/RegData/docs_autres_institutions/commission_europeenne/com/2020/0712/COM_COM(2020)0712_EN.pdf ], Accessed 13 April 2021

6. Lord Chief Justice of England And Wales, First International Forum on Online Courts: the Cutting Edge of Digital Reform, 2018, [https:/www.judiciary.uk/wp-content/uploads/2018/12/ speech-lcj-online-court.pdf], Accessed 13 April 2021

7. Ryan, M.; Harker, L.; Rothera S., Remote hearings in the family justice system: reflections and experiences, Nuffield Family Justice Observatory/The Legal Education Foundation,, 2020, [https://www.nuffieldfjo.org.uk/app/nuffield/files-module/local/documents/remote_hearings_sept_2020.pdf], Accessed 13 April 2021

8. Sourdin, T. et al., COVID-19, Technology and Family Dispute Resolution, 2020, [https://papers.ssrn.com/sol3/papers.cfm?abstract_id=3672995], Accessed 13 April 2021

9. Survey on the Accelerate digitization to increase resilience, Deloitte, 2020, [https://www2.deloitte.com/content/dam/Deloitte/global/Documents/Legal/dttl-legal-covid-respond-legaldigitization.pdf], Accessed 13 April 2021

10. Velicogna, M., Cross-border Civil Litigation in the EU: What can we learn from COVID-19 emergency National e-Justice experiences?, 'e' Meets Justice webcast, 2020, [https:// papers.ssrn.com/sol3/Delivery.cfm/SSRN_ID3737648_code835984.pdf?abstractid=37376 48\&mirid=1], Accessed 13 April 2021 